\title{
Effects of ocean acidification on the larvae of a high-value pelagic fisheries species, mahi-mahi Coryphaena hippurus
}

\author{
Sean Bignami ${ }^{1,4, *}$, Su Sponaugle ${ }^{1,2,3}$, Robert K. Cowen ${ }^{1,3}$ \\ ${ }^{1}$ Division of Marine Biology and Fisheries, Rosenstiel School of Marine and Atmospheric Science, University of Miami, \\ Miami, FL 33149, USA \\ ${ }^{2}$ Department of Integrative Biology, Oregon State University, Corvallis, OR 97331, USA \\ ${ }^{3}$ Hatfield Marine Science Center, Oregon State University, Newport, OR 97365, USA \\ ${ }^{4}$ Present address: Concordia University Irvine, Irvine, CA 92612, USA
}

\begin{abstract}
Negative impacts of $\mathrm{CO}_{2}$-induced ocean acidification on marine organisms have proven to be variable both among and within taxa. For fishes, inconsistency confounds our ability to draw conclusions that apply across taxonomic groups and highlights the limitations of a nascent field with a narrow scope of study species. Here, we present data from a series of 3 experiments on the larvae of mahi-mahi Coryphaena hippurus, a large pelagic tropical fish species of high economic value. Mahi-mahi larvae were raised for up to $21 \mathrm{~d}$ under either ambient seawater conditions (350 to $490 \mu \mathrm{atm} p \mathrm{CO}_{2}$ ) or projected scenarios of ocean acidification (770 to $2170 \mu \mathrm{atm}$ $p \mathrm{CO}_{2}$ ). Evaluation of hatch rate, larval size, development, swimming activity, swimming ability $\left(U_{\text {crit }}\right)$, and otolith (ear stone) formation produced few significant effects. However, larvae unexpectedly exhibited significantly larger size-at-age and faster developmental rate during 1 out of 3 experiments, possibly driven by metabolic compensation to elevated $p \mathrm{CO}_{2}$ via a corresponding decrease in routine swimming velocity. Furthermore, larvae had significantly larger otoliths at $2170 \mu$ atm $p \mathrm{CO}_{2}$, and a similar but non-significant trend also occurred at $1200 \mu \mathrm{atm} p \mathrm{CO}_{2}$, suggesting potential implications for hearing sensitivity. The lack of effect on most variables measured in this study provides an optimistic indication that this large tropical species, which inhabits the offshore pelagic environment, may not be overly susceptible to ocean acidification. However, the presence of some treatment effects on growth, swimming activity, and otolith formation suggests the presence of subtle, but possibly widespread, effects of acidification on larval mahi-mahi, the cumulative consequences of which are still unknown.
\end{abstract}

KEY WORDS: Ocean acidification $\cdot$ Larval fish $\cdot$ Otolith $\cdot$ Mahi-mahi $\cdot \mathrm{CO}_{2} \cdot U_{\text {crit }} \cdot$ Behavior

\section{INTRODUCTION}

A diversity of marine organisms are negatively affected by $\mathrm{CO}_{2}$-induced ocean acidification, yet the occurrence and severity of such effects are highly variable among taxa and life history stages (Kroeker et al. 2013). While much research has focused on calcifying marine invertebrates, until recently there has been relatively little consideration of acidifica-

*Corresponding author: sean.bignami@cui.edu tion impacts on fishes. This is due, in part, to the fact that adult fishes and other organisms with high metabolic rates are relatively efficient at regulating their internal acid-base balance in response to metabolic or environmental disturbances, and thus are considered to be more capable of resisting the effects of ocean acidification (Melzner et al. 2009a). Unfortunately, there are few comparable data on the ability of early life history stages of fishes to 
cope with increased environmental partial pressure of carbon dioxide $\left(p \mathrm{CO}_{2}\right)$. Embryonic and larval fishes are not equipped with the same physiological mechanisms as juveniles and adults, but are capable of some internal pH regulation (Brauner 2008). Nonetheless, existing literature indicates that early life stages of fishes are more susceptible to elevated $p \mathrm{CO}_{2}$ relative to adults (reviewed by Pörtner et al. 2005). As the primary period of dispersal for many marine fishes, the larval stage is critical to population replenishment and connectivity (Cowen \& Sponaugle 2009); therefore, our understanding of the broader population- and ecosystem-level impacts of ocean acidification requires consideration of this life stage.

The impact of ocean acidification on larval fishes is highly variable among studies and taxa. The range of effects include reduced growth and survival (Baumann et al. 2011), skeletal deformation (Pimentel et al. 2014a), altered neurological function (Nilsson et al. 2012), and disrupted behavior (Munday et al. 2010, Ferrari et al. 2012, Hamilton et al. 2014). Some species have experienced more discrete effects, such as altered otolith (ear stone) development (Checkley et al. 2009, Munday et al. 2011a, Hurst et al. 2012, Bignami et al. 2013a) and impaired tissue health (Frommel et al. 2011). Several other studies report no $p \mathrm{CO}_{2}$ effects on fish larvae (e.g. Munday et al. 2011b, Frommel et al. 2013). Though intriguing, this interand intra-specific variability in response to ocean acidification confounds our ability to formulate general conclusions regarding the fate of fish populations under future environmental scenarios. To better clarify the underlying factors driving patterns of susceptibility or resistance to ocean acidification, it is necessary to examine a diversity of species with distinct differences in life history strategies, physiological capabilities, and habitat use. To date, most studies of ocean acidification impacts on fish larvae have focused on demersal, reef-associated species, with few large pelagic species represented in the literature (except see Checkley et al. 2009, Bignami et al. 2013a,b, Pimentel et al. 2014b).

Fishes with a strictly offshore pelagic life history spawn pelagic eggs, undergo planktonic larval development, and live as juveniles and adults in an offshore environment that lacks the extreme diurnal cycles in $\mathrm{pH}$ and temperature observed in shallow coastal environments (Hofmann et al. 2011, Frieder et al. 2012, Price et al. 2012). It has been suggested that pelagic species that have adapted to such a stable environment may be more susceptible to future environmental changes, such as ocean acidification, compared to demersal species that regularly experience fluctuating environmental conditions (Munday et al. 2008, Pörtner 2008). Prior studies on larval cobia Rachycentron canadum and mahi-mahi Coryphaena hippurus have shown variable impacts of ocean acidification on these tropical pelagic fishes. In particular, cobia larvae have shown some resistance to direct impacts of ocean acidification on growth, development, swimming activity, and swimming ability (Bignami et al. 2013a), although larvae exhibited altered otolith formation, which has implications for auditory sensation (Bignami et al. 2013b). However, cobia also use nearshore environments, and the evolution of adaptations to withstand such variable environmental conditions may reduce their susceptibility to acidification (Bignami et al. 2013a). Conversely, very young mahi-mahi larvae exhibit metabolic depression and behavioral changes under elevated $p \mathrm{CO}_{2}$ conditions (Pimentel et al. 2014b). Mahi-mahi, a large tropical pelagic species of high economic value, has an entirely pelagic life history and their response to ocean acidification may be more representative of other strictly pelagic species.

In this study, we examined the response of larval mahi-mahi to predicted levels of ocean acidification. We present data from a series of experiments that investigated a suite of factors that are comparable to those reported for larval cobia and other species, including hatch rate, growth, development, swimming activity, critical swimming speed ( $\left.U_{\text {crit }}\right)$, and otolith formation (Munday et al. 2009, Baumann et al. 2011, Bignami et al. 2013a). We hypothesized that mahi-mahi would be more susceptible to acidification than species adapted to more variable natural environments. Thus, we expected larvae exposed to elevated $p \mathrm{CO}_{2}$ treatments to exhibit reduced growth and development, altered swimming activity, diminished swimming ability, and enhanced otolith growth.

\section{MATERIALS AND METHODS}

\section{Study species}

Mahi-mahi Coryphaena hippurus is a highly migratory, epipelagic, predatory marine fish with a circumglobal distribution in tropical to subtropical waters (Palko et al. 1982, FAO 2013). Spawning of pelagic eggs occurs throughout the year, primarily during warmer months $\left(>24^{\circ} \mathrm{C}\right.$, April to November), with planktonic larvae that hatch at $\sim 3.5 \mathrm{~mm}$ standard length (SL), undergo flexion at $\sim 7$ to $9 \mathrm{~mm} \mathrm{SL}$, 
and develop via a gradual transition into the pelagic juvenile stage (Ditty et al. 1994). Mahi-mahi grow rapidly and are capable of hatching, developing, and reaching reproductive maturity in as little as 4 mo (Beardsley 1967, Oxenford 1999). Maximum size is as large as $2 \mathrm{~m}$ and over $30 \mathrm{~kg}$, however, longevity is short compared with other pelagic species, with an average of $2 \mathrm{yr}$ and maximum of 4 to $5 \mathrm{yr}$ (Beardsley 1967, FAO 2013). The species is highly targeted by commercial, artisanal, and recreational fisheries throughout its distribution (Potoschi et al. 1999, Folpp \& Lowry 2006, Zúñiga Flores et al. 2008) and is one of the top 7 harvested pelagic species in the western central Atlantic (Oxenford 1999). It has high commercial value, with global fishery landings of over 57000 tons in 2008 (FAO 2013).

\section{Experimental design and water chemistry}

Three experiments were conducted to assess the effects of elevated $p \mathrm{CO}_{2}$ on mahi-mahi larvae. In each experiment, ambient seawater was utilized as a control (350 to 490 uatm $p \mathrm{CO}_{2}$, Table 1). One (during Expt 1) or 2 (during Expts 2 and 3) elevated $p \mathrm{CO}_{2}$ treatments ranging from 770 to 2170 atm $p \mathrm{CO}_{2}$ were applied to simulate projected scenarios of ocean acidification over the next 2 centuries (Caldeira \& Wickett 2003, 2005, Meehl et al. 2007), as well as present-day conditions in some nearshore marine environments (Feely et al. 2008, Thomsen et al. 2010, Melzner et al. 2013). Elevated $p \mathrm{CO}_{2}$ treatments between 770 and 1600 ratm correspond to RCP8.5 projections that may be reached within the next 75 to $150 \mathrm{yr}$, while the 2170 ratm $p \mathrm{CO}_{2}$ treat- ment slightly exceeds RCP8.5 projections through year 2300 (Meinshausen et al. 2011).

Seawater carbonate chemistry was manipulated by the addition of equimolar $\mathrm{HCl}$ and $\mathrm{NaHCO}_{3}$ to seawater prior to introduction into tanks (Gattuso 2010, Bignami et al. 2013a; see Table 1 for water parameter summary). Tank pH was monitored daily using a handheld pH meter (pH11, Oakton) and Ross Electrode (Orion 9102BWNP, Thermo Scientific) calibrated daily with TRIS buffer. Water samples were collected every $5 \mathrm{~d}$ in $250 \mathrm{ml}$ PET bottles, fixed with $100 \mu \mathrm{l}$ of saturated mercuric chloride, and the total alkalinity (TA) and $\mathrm{pH}_{\mathrm{T}}$ were measured using automated Gran titration checked for accuracy with Dickson standards (Scripps Institution of Oceanography; Langdon et al. 2000). CO2SYS was used to solve the carbonate system using the 2 measured parameters $\left(\mathrm{pH}_{\mathrm{T}}\right.$ and $\mathrm{TA}_{\text {; }}$ Lewis \& Wallace 1998). Temperature and dissolved oxygen were measured with a combination meter (550A, YSI) twice and once per day, respectively, and salinity was measured once per day using a refractometer (RHS-10 ATC, Premium Aquatics). During Expts 1 and 3, ambient $p \mathrm{CO}_{2}$ of seawater was 50 to 200 uatm higher than expected, likely due to respiration in the source seawater (Biscayne Bay, Florida) and within the facility plumbing, but was well below elevated $p \mathrm{CO}_{2}$ treatment levels. This did not occur during Expt 2. Although temperature was stable within each experiment, there were differences among experiments due to seasonal changes in source seawater and limited heating capability in the rearing system. Due to differences in $p \mathrm{CO}_{2}$ and temperature between experiments, direct comparison of results between Expts 1, 2, and 3 is not intended.
Table 1. Water chemistry conditions during Expts 1, 2, and 3. Temperature, $\mathrm{pH}$, and total alkalinity (TA) were measured and mean $p \mathrm{CO}_{2}$ calculated with the software CO2SYS (Lewis \& Wallace 1998). Values are means \pm SE

\begin{tabular}{|c|c|c|c|c|}
\hline Treatment level & $\begin{array}{l}\text { Temp. } \\
\left({ }^{\circ} \mathrm{C}\right)\end{array}$ & $\mathrm{pH}_{\mathrm{T}}$ & $\begin{array}{c}\text { TA } \\
\left.(\mu \mathrm{mol} \mathrm{kg})^{-1}\right)\end{array}$ & $\begin{array}{c}p \mathrm{CO}_{2} \\
\text { ( } \mu \mathrm{atm})\end{array}$ \\
\hline \multicolumn{5}{|l|}{ Expt 1} \\
\hline Ambient/control & $23.9 \pm 0.2$ & $8.00 \pm 0.01$ & $2457 \pm 22$ & $487 \pm 24$ \\
\hline $1600 \mu \mathrm{atm} p \mathrm{CO}_{2}$ & $23.9 \pm 0.2$ & $7.54 \pm 0.01$ & $2462 \pm 22$ & $1595 \pm 85$ \\
\hline \multicolumn{5}{|l|}{ Expt 2} \\
\hline Ambient/control & $25.3 \pm 0.2$ & $8.11 \pm 0.005$ & $2387 \pm 24$ & $348 \pm 17$ \\
\hline $770 \mu \mathrm{atm} p \mathrm{CO}_{2}$ & $25.3 \pm 0.2$ & $7.82 \pm 0.01$ & $2384 \pm 23$ & $767 \pm 52$ \\
\hline $1460 \mu$ atm $p \mathrm{CO}_{2}$ & $25.3 \pm 0.2$ & $7.56 \pm 0.01$ & $2394 \pm 23$ & $1461 \pm 56$ \\
\hline \multicolumn{5}{|l|}{ Expt 3} \\
\hline Ambient/control & $28.1 \pm 0.2$ & $7.99 \pm 0.01$ & $2326 \pm 30$ & $454 \pm 17$ \\
\hline $1190 \mu \mathrm{atm} p \mathrm{CO}_{2}$ & $28.1 \pm 0.2$ & $7.62 \pm 0.01$ & $2320 \pm 28$ & $1189 \pm 65$ \\
\hline 2170 uatm $p \mathrm{CO}_{2}$ & $28.1 \pm 0.2$ & $7.38 \pm 0.02$ & $2332 \pm 43$ & $2172 \pm 159$ \\
\hline
\end{tabular}

\section{Larval rearing}

All experiments were conducted using adapted methodology for the rearing of larval cobia (Benetti et al. 2008, Bignami et al. 2013a), described briefly here. Mahi-mahi eggs and larvae for each experiment were produced at the University of Miami Experimental Hatchery (UMEH) from a population of 3 wild-caught broodstock (2 females, 1 male). Mahi-mahi eggs were collected within $12 \mathrm{~h}$ of evening/nighttime spawning, gently transferred into an aerated 3001 fiberglass tank, and provided with a $1 \mathrm{~h}$ 
formalin sterilization treatment (100 ppm) followed by rapid flushing of seawater, and transferred to either an incubator tank or an experimental tank. Experimental tanks received filtered, UV-sterilized seawater at an exchange rate of $\sim 400 \% \mathrm{~d}^{-1}$ and were aerated with a small amount $\left(<11 \mathrm{~min}^{-1}\right)$ of bubbled air. Tanks were partially submerged in a large water bath to maintain replicate tank temperatures within $\pm 0.2^{\circ} \mathrm{C}$ of each other, positioned under $95 \%$ shade cloth to reduce light intensity, and fitted with translucent white polyethylene lids to prevent $\mathrm{CO}_{2}$ offgassing, intrusion of rain water, or introduction of contaminants.

During Expt 1, eggs were hatched within $~ 36 \mathrm{~h}$ in a 10001 incubator tank where they were allowed to develop until 2 days post hatch (dph). Then, larvae were stocked into 6 replicated 4001 flow-through experimental tanks per treatment, at a density of 9 to 10 eggs $1^{-1}$. During Expts 2 and 3, eggs were stocked directly into 4 replicated experimental tanks per treatment immediately following sterilization treatment, to expose them to elevated $p \mathrm{CO}_{2}$ conditions during a possible window of susceptibility in early development (Baumann et al. 2011). Acidification treatments were initiated just prior to stocking, reaching full strength within $12 \mathrm{~h}$. In all experiments, feeding began at $2 \mathrm{dph}$ with the addition of enriched rotifers, Brachionus plicatilis, 4 or 5 times $\mathrm{d}^{-1}$, providing total densities of 3 to 8 rotifers $\mathrm{ml}^{-1} \mathrm{~d}^{-1}$ for larvae $2 \mathrm{dph}$ to 10 or 12 dph (depending on larval size), gradually increasing with age (Benetti et al. 2008). Beginning at 5 to $8 \mathrm{dph}$ (depending on larval size), larvae were also provided enriched Artemia nauplii at total densities of 0.25 to $1.5 \mathrm{ml}^{-1} \mathrm{~d}^{-1}$, gradually increasing with age (Benetti et al. 2008). Greenwater rearing techniques were utilized to provide supplemental nutrients and increase tank turbidity, which has been shown to improve larval feeding and survival in other species (Naas et al. 1992, Faulk \& Holt 2005). Between 1 and $12 \mathrm{dph}$, we added 15 to $20 \mathrm{ml} \mathrm{d}^{-1}$ of a concentrated blend of whole cell suspended microalgae (RotiGreen Omega, Reed Mariculture) to rearing tanks throughout the day along with rotifer feedings, maintaining a level of turbidity in which visibility of the tank bottom ( $75 \mathrm{~cm}$ depth) was obscured.

Throughout all experiments, mortality rates were estimated visually but were not measured quantitatively due to practical limitations. Daily mortality rates were highly variable throughout ontogeny, which is a common scenario during intensive rearing of mahi-mahi larvae at UMEH. Cumulative mortality rates were estimated to reach as high as the mid-90th percentile, regardless of treatment. During Expts 1 and 2, equipment failure (air flow and water supply) resulted in complete mortality of larvae in some tanks, forcing premature termination (prior to $21 \mathrm{dph}$ ) of Expts 1 and 2, and analysis was limited to those data collected prior to the failures. During Expts 1, 2, and 3, rearing continued until 17, 13, and $21 \mathrm{dph}$, respectively.

\section{Hatch rate, size, and development}

While stocking experimental tanks during Expts 2 and 3, 50 eggs from each replicate tank were reserved and placed into a closed 11 high-density polyethylene jar with a $300 \mu \mathrm{m}$ nylon mesh window and flow-through seawater. During Expt 2, these chambers were suspended in each tank until hatching in experimental tanks was observed to be complete, at which point chambers were retrieved and eggs/larvae preserved for later analysis of hatch rate and size. To determine if embryonic duration varied with $\mathrm{CO}_{2}$ treatment, during Expt 3, hatching chambers were collected at a set time (sundown), while hatching in experimental tanks was still in progress. Throughout each experiment, subsamples of 5 to 20 larvae were collected from each replicate tank throughout ontogeny, specifically targeting the period of transition from pre-flexion through postflexion. During Expt 3, fewer sampling days were selected to ensure sufficient sample sizes for swimming tests at 20 dph. Larvae were stored in $95 \%$ ethanol, a digital image of each larva was captured, and SL was measured to the nearest $0.1 \mathrm{~mm}$ using the software Image-Pro Plus (v7.0, MediaCybernetics). We qualitatively assessed progression through flexion according to notochord position (i.e. flexing upwards) and development of caudal fin rays, scoring each larva as 'pre-flexion' or 'undergoing/post-flexion'.

\section{Swimming activity and ability}

Swimming activity tests were performed at $8 \mathrm{dph}$ during Expts 1 and 2 according to previous techniques (Bignami et al. 2013a), described briefly here. Prior to the first daily feeding, 3 subsamples of 5 larvae each were removed from each replicate tank for swimming activity observations. Larvae were allowed to acclimate to a $15 \mathrm{~cm}$ diameter observation container for at least $1 \mathrm{~h}$. Following acclimation, each container of 5 larvae was placed individually on a clear shelf inside an enclosed PVC observation chamber with a translucent lid and allowed to re- 
cover for 2 min. Larval routine swimming activity was recorded for 2 min using a low-light video camera (Hi-Res EXvision, Super Circuits) set $40 \mathrm{~cm}$ beneath the observation chamber. Directly following routine swimming observation, a pipette was used to gently add $1 \mathrm{ml}$ of an olfactory stimulant to the center of the observation dish, and swimming activity in response to olfactory stimulation was recorded for an additional 2 min. During Expt 1, food-scented water (30 $\mu \mathrm{m}$ filtered rotifer culture water) was used as an olfactory stimulant. A different olfactory stimulant was used during Expt 2: chemical alarm cues, which are known to be released by a diversity of fish taxa upon damage to the skin (Mathis et al. 1995, Brown 2003, Holmes \& McCormick 2010). Prior to behavioral observations, a single $2.5 \mathrm{~cm}$ juvenile mahimahi was anesthetized with $10 \%$ quinaldine, euthanized by immersion in MS-222, and rinsed with seawater. Both sides of the fish were scored with a blade and it was submerged in $100 \mathrm{ml}$ of seawater for $10 \mathrm{~min}$. This suspension was subsequently used as the olfactory stimulant.

Observation videos were converted to digital files, reduced to 2 frames $\mathrm{s}^{-1}$, and analyzed for mean and maximum swimming speed, average angle change between $0.5 \mathrm{~s}$ observation points, and net-to-gross displacement (del Carmen Alvarez \& Fuiman 2005) with the software ImageJ (v1.46p, National Institutes of Health) using the MTrackJ plug-in (Meijering et al. 2012). Individual larvae were tracked over the entire 2 min routine swimming and subsequent $2 \mathrm{~min}$ olfactory stimulation observation periods. To capture periods of active swimming, and because larvae were sometimes stationary for extended periods of time, analyses of average angle change and net-togross displacement were performed on 1 randomly selected $20 \mathrm{~s}$ period of active swimming per larva (defined as a minimum of $5 \mathrm{~cm}$ gross distance traveled in $20 \mathrm{~s}$ ).

$U_{\text {crit }}$ was measured during Expt 3 for 20 dph postflexion fish using a 6 lane swimming flume similar to that described by Munday et al. (2009). Larvae were tested in their respective $\mathrm{CO}_{2}$ treatment groups by adding equimolar $\mathrm{HCl}$ and $\mathrm{NaHCO}_{3}$ to the large, recirculating seawater reservoir connected to the flume. This required larvae to be tested in order of increasing $p \mathrm{CO}_{2}$ treatment, beginning with ambient seawater and ending with the highest treatment. $U_{\text {crit }}$ was measured using the same methodology as Bignami et al. (2013a), modified from Stobutzki \& Bellwood (1997) and described briefly here.

Prior to $U_{\text {crit }}$ testing, subsamples of 6 larvae were collected in $1 \mathrm{l}$ containers from each replicate tank be- fore the first daily feeding. Larvae were allowed to acclimate to flume water conditions for at least $1 \mathrm{~h}$ before being randomly assigned lanes and allowed to acclimate to the flume for $5 \mathrm{~min}$ at a current speed of $2 \mathrm{~cm} \mathrm{~s}^{-1}$. During $U_{\text {crit }}$ testing, water current speed was increased by approximately $3 \mathrm{~cm} \mathrm{~s}^{-1}$ at 2 min intervals until larvae failed to maintain their position and were swept against a mesh barrier at the end of each flume lane. Flow calibration was verified using dye immediately before and after the day of testing, and $U_{\text {crit }}$ speeds were calculated in body lengths $\mathrm{s}^{-1}$ using the equation $\left.U_{\text {crit }}=V_{\mathrm{p}}+\left[\left(t_{\mathrm{f}} / t_{\mathrm{i}}\right) \times V_{\mathrm{i}}\right)\right]$, where $V_{\mathrm{p}}$ is the penultimate velocity increment successfully completed for the full time interval $\left(t_{\mathrm{i}}\right)$, prior to the velocity increment at which failure occurred $\left(V_{\mathrm{i}}\right)$ at a failure time $\left(t_{\mathrm{f}}\right)$ less than the full time interval (Hammer 1995).

\section{Otolith analysis}

During Expt 3, left and right sagittal and lapillar otoliths were dissected from four $21 \mathrm{dph}$ larvae per replicate tank (total of 16 treatment $^{-1}$ ), stored in medium viscosity immersion oil, and imaged sulcus side down under a total magnification of 400x. Using Image-Pro Plus (v7.0) software, we digitally outlined each otolith according to pixel contrast and collected measurement data for dimensions including area, length, width, rectangularity, and roundness (otolith area divided by the area of the smallest rectangle able to contain it, and otolith perimeter divided by the circumference of the smallest circle able to contain it, respectively; Munday et al. 2011a,b). Otolith dimensions were scaled according to the SL of each larva.

\section{Data analysis}

All statistical analyses were conducted in $\mathrm{R}$ (v2.15.1) using tank mean data, and results were considered significant at $\mathrm{p}<0.05$. SL, proportion of fish having entered flexion, $U_{\text {crit, }}$ swimming activity metrics, and left sagittal and left lapillar otolith shape (roundness and rectangularity) data were analyzed using 1-way ANOVA with $\mathrm{CO}_{2}$ as a fixed factor and the respective measurement as the response variable. Otolith size metrics were tested using ANCOVA procedures, with each metric as a response variable, $p \mathrm{CO}_{2}$ as a fixed factor, and SL as a continuous covariate. In the event that one treatment exhibited a significantly different regression slope, that treatment was removed from further analysis. Arcsine transformations were applied to the proportion 
of fish having entered flexion. Normality and homoscedasticity were verified using Shapiro-Wilk and Bartlett's tests prior to all statistical procedures. Although the majority of data met all assumptions for ANOVA, during Expt 2, tank mean SL data from control treatments were not normally distributed on $13 \mathrm{dph}$ and tank mean data of net-to-gross displacement were heteroscedastic across treatments. However, underlying distributions of subsampled fish were normal and homoscedastic. ANOVA procedures were conducted because of this underlying normality and because $F$-values are robust to departures from normality and homoscedasticity, with negligible to modest inflation of Type I error (Harwell et al. 1992, Underwood 1997).

\section{RESULTS}

Expt 1: The SL of larvae during Expt 1 was not significantly affected by elevated $p \mathrm{CO}_{2}$ treatments for any sampling day $(5,8-12 \mathrm{dph}$, all $\mathrm{p}>0.05$; Fig. 1a). Larvae collected at the termination of Expt 1 (17 dph) showed a similar trend, but statistical analyses were not conducted due to the aforementioned high mortality in some replicate tanks. Larval progression through flexion was not affected by elevated $p \mathrm{CO}_{2}$ treatments on any targeted sampling day, ranging from 9 to 12 dph (all p > 0.05; Fig. 1b). Similarly, no metric of routine swimming activity was affected by $\mathrm{CO}_{2}$ treatment, and larvae did not exhibit any treatment-related change in swimming activity following olfactory stimulation with food-scented water (all $p>0.05$ ). See Table 2 for summary statistics from all Expt 1 analyses.

Expt 2: Hatch rate (>95\% in all treatments) and size-at-hatch were not significantly affected by $\mathrm{CO}_{2}$ treatment during Expt 2 (both $\mathrm{p}>0.05$; data not shown), but larvae demonstrated significantly increased SL under both elevated $p \mathrm{CO}_{2}$ treatments (770 and $1460 \mu \mathrm{atm} p \mathrm{CO}_{2}$ ) compared to controls at $5 \mathrm{dph}(\mathrm{p}=0.017$; Fig. $2 \mathrm{a})$. A similar result was found at the highest treatment level at $8 \mathrm{dph}(\mathrm{p}=0.032)$, but not at 9 or $13 \mathrm{dph}$. Correspondingly, a significantly higher proportion of larvae were undergoing flexion at $8 \mathrm{dph}$ in the $1460 \mu \mathrm{atm} p \mathrm{CO}_{2}$ treatment compared to controls ( $p=0.035$; Fig. $2 b$ ). By the second day of sampling for flexion, nearly all larvae had begun to flex and no significant differences were evident. Routine swimming activity was significantly impacted by $\mathrm{CO}_{2}$ treatment for 1 metric: larvae from the 1460 atm $p \mathrm{CO}_{2}$ treatment level exhibited significantly lower maximum swimming velocity compared
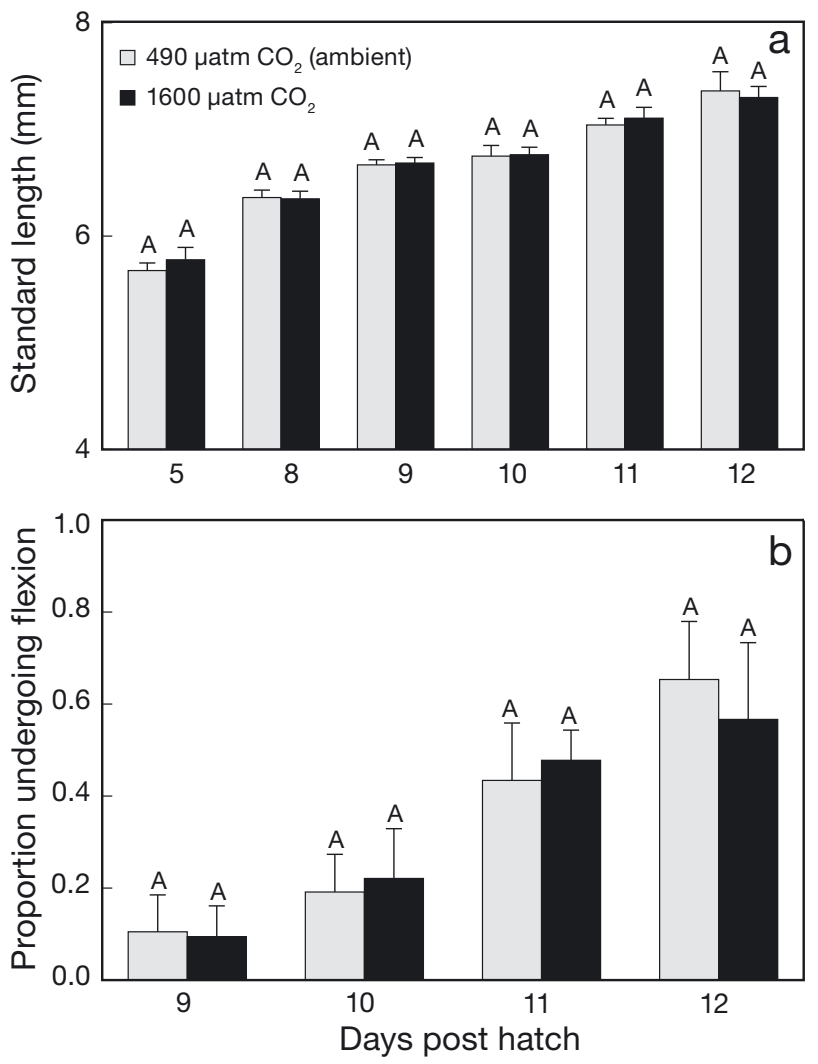

Fig. 1. Effects of ocean acidification on larval mahi-mahi (a) size-at-age and (b) proportion of larvae undergoing flexion during Expt 1. Within each day post hatch (dph), bars that share a letter are statistically similar (ANOVA, $p>0.05$ ). Values are tank means (a) $+\mathrm{SE}$ and $(\mathrm{b})+\mathrm{SD}_{;} \mathrm{n}=6$ treatment $^{-1}$

Table 2. Summary of statistical results from ANOVA of standard length (SL), flexion, and routine swimming activity of mahi-mahi larvae across multiple days post hatch (dph) during Expt 1

\begin{tabular}{|lccc|}
\hline Metric & $F$ & $\mathrm{p}$ & $\mathrm{df}$ \\
\hline SL (dph) & & & \\
5 & 0.557 & 0.473 & 1,10 \\
8 & 0.014 & 0.909 & 1,10 \\
9 & 0.058 & 0.814 & 1,10 \\
10 & 0.012 & 0.915 & 1,10 \\
11 & 0.286 & 0.605 & 1,10 \\
12 & 0.089 & 0.772 & 1,10 \\
Flexion (dph) & & & \\
9 & 0.061 & 0.810 & 1,10 \\
10 & 0.293 & 0.601 & 1,10 \\
11 & 0.527 & 0.484 & 1,10 \\
12 & 0.966 & 0.349 & 1,10 \\
Swimming activity & & & \\
Mean velocity & 2.535 & 0.142 & 1,10 \\
Max velocity & 0.117 & 0.740 & 1,10 \\
Net-to-gross displacement & 0.892 & 0.367 & 1,10 \\
Angle change & 0.574 & 0.466 & 1,10 \\
\hline
\end{tabular}



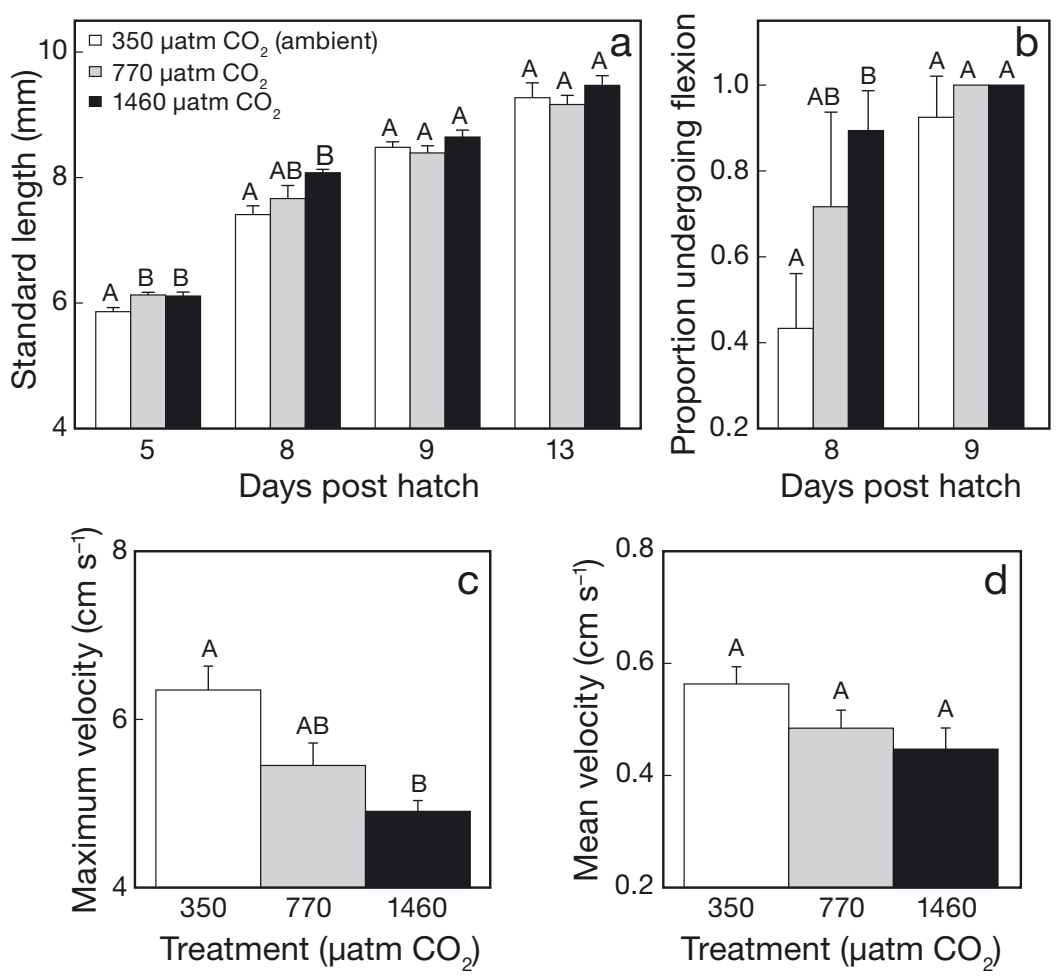

Fig. 2. Effects of ocean acidification on larval mahi-mahi (a) size-at-age, (b) proportion of larvae undergoing flexion, (c) maximum routine swimming velocity, and (d) mean routine swimming velocity during Expt 2 . Bars not sharing a letter (within each day post hatch in panels a and b) are significantly different (Tukey's test, $\mathrm{p}<0.05)$. Values are tank means $(\mathrm{a}, \mathrm{c}, \mathrm{d})+\mathrm{SE}$ and $(\mathrm{b})+\mathrm{SD} ; \mathrm{n}=4$ treatment $^{-1}$
1190 uatm $p \mathrm{CO}_{2}$ treatment were of intermediate size and not significantly different from either treatment or controls (all p > 0.05), with the exception of the left sagitta being significantly wider compared to controls ( $p<0.001)$. The regression of lapillus length and area against SL from the 1190 uatm $p \mathrm{CO}_{2}$ treatment did not satisfy the assumption of equal slopes compared to ambient and $2170 \mu \mathrm{atm}$ $p \mathrm{CO}_{2}$ treatments, and was removed from further analysis. There were no significant differences in otolith roundness or rectangularity between any treatments $(\mathrm{p}>0.05)$. See Table 4 for summary statistics from all Expt 3 analyses.

\section{DISCUSSION}

Contrary to our original hypotheses, mahi-mahi larvae were not particularly susceptible to ocean acidification, exhibiting no negative effects on hatch rate, size, development, or swimming ability. However, young to controls ( $p=0.006$; Fig. 2c). A similar trend was observed for mean swimming velocity, but this pattern was not significant ( $p=0.093$; Fig. 2d). Angle change and net-to-gross-displacement were not significantly affected by $\mathrm{CO}_{2}$ treatment, and there were no significant treatment effects on swimming activity following olfactory stimulation with conspecific chemical alarm cue (all p > 0.05). See Table 3 for summary statistics from all Expt 2 analyses.

Expt 3: Both elevated $p \mathrm{CO}_{2}$ treatments (1190 and 2170 atm $p \mathrm{CO}_{2}$ ) exhibited a trend of lower proportion of eggs hatched compared to controls, but this trend was not significant ( $p=0.076$; Fig. 3a). There were no significant differences in the SL of larvae on any sampling day $(2,6$, and $21 \mathrm{dph}$, all p > 0.05; Fig. 3b) and fish were not sampled to analyze progression through flexion. Larvae tested for $U_{\text {crit }}$ at $20 \mathrm{dph}$ demonstrated a trend of lower $U_{\text {crit }}$ with increasing $p \mathrm{CO}_{2}$, but this pattern was not significant ( $\mathrm{p}=0.179$; Fig. 3c).

Left sagittal and lapillar otolith length, width, and area were all significantly larger in larvae from the $2170 \mu$ atm $p \mathrm{CO}_{2}$ treatment compared to controls (all $\mathrm{p}<0.05$; Fig. 4a-c). Otoliths from larvae in the
Table 3. Summary of statistical results from ANOVA of proportion of mahi-mahi larvae hatched (Hatch), standard length (SL), flexion, and routine swimming activity across multiple days post hatch (dph) during Expt 2. Significant results $(\mathrm{p}<0.05)$ are shown in bold. Tukey's post-hoc test results compare ambient $p \mathrm{CO}_{2}(\mathrm{C}), 770 \mu$ atm $p \mathrm{CO}_{2}$ (1), and $1460 \mu \mathrm{atm} p \mathrm{CO}_{2}(2)$ treatments

\begin{tabular}{|lcccc|}
\hline Metric & $F$ & $\mathrm{p}$ & $\mathrm{df}$ & Tukey's \\
\hline Hatch & 0.685 & 0.528 & 2,9 & $\mathrm{C}=1=2$ \\
SL (dph) & & & & \\
0 & 0.598 & 0.570 & 2,9 & $\mathrm{C}=1=2$ \\
5 & 6.635 & $\mathbf{0 . 0 1 7}$ & 2,9 & $\mathrm{C}<1=2$ \\
8 & 5.191 & $\mathbf{0 . 0 3 2}$ & 2,9 & $1=\mathrm{C}<2=1$ \\
9 & 1.512 & 0.272 & 2,9 & $\mathrm{C}=1=2$ \\
13 & 0.866 & 0.457 & 2,8 & $\mathrm{C}=1=2$ \\
Flexion (dph) & & & & \\
8 & 4.988 & $\mathbf{0 . 0 3 5}$ & 2,9 & $\mathrm{C}<1=2$ \\
9 & 2.835 & 0.112 & 2,9 & $\mathrm{C}=1=2$ \\
Swimming activity & & & & \\
Mean velocity & 3.122 & 0.093 & 2,9 & $\mathrm{C}=1=2$ \\
Max velocity & 9.454 & $\mathbf{0 . 0 0 6}$ & 2,9 & $\mathrm{C}<1=2$ \\
Net-to-gross & 0.321 & 0.734 & 2,9 & $\mathrm{C}=1=2$ \\
\multicolumn{1}{l}{ displacement } & & & & \\
Angle change & 0.021 & 0.980 & 2,9 & $\mathrm{C}=1=2$ \\
\hline
\end{tabular}



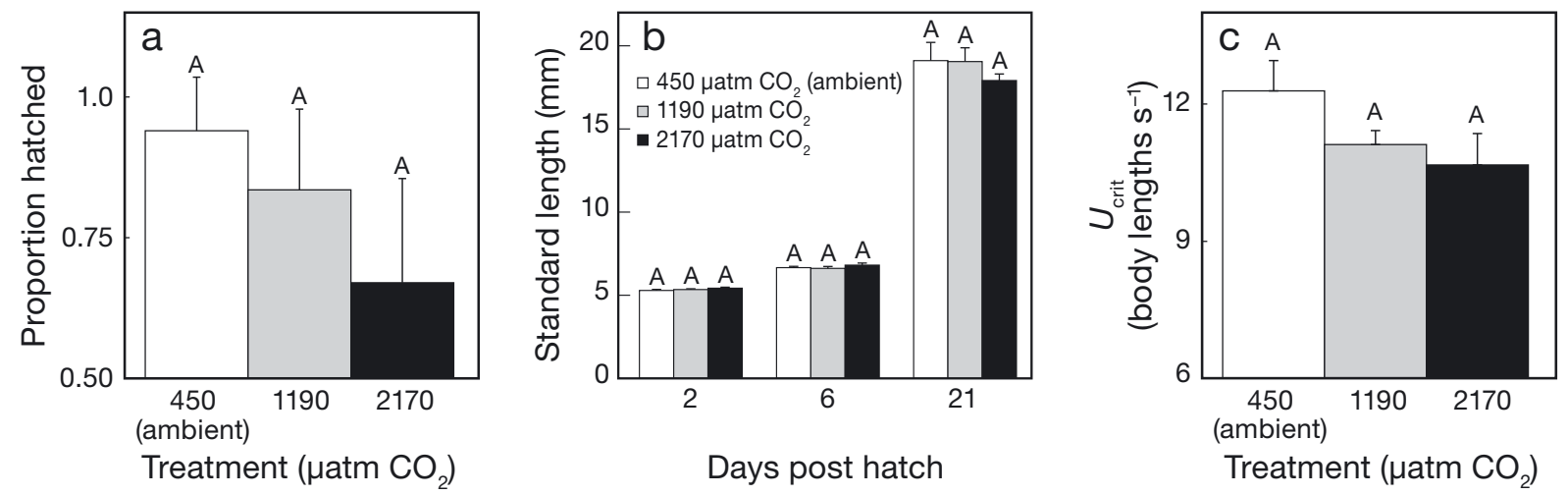

Fig. 3. Effects of ocean acidification on (a) the proportion of mahi-mahi eggs hatched, (b) size-at-age, and (c) critical swimming speed ( $U_{\text {crit }}$ ) of 20 day post hatch (dph) larvae during Expt 3. Bars sharing a letter (within each dph in panel b) are statistically similar (Tukey's test, $\mathrm{p}>0.05$ ). Values are tank means $(\mathrm{a})+\mathrm{SD}$ and $(\mathrm{b}, \mathrm{c})+\mathrm{SE}_{\mathrm{i}} \mathrm{n}=4$ treatment $^{-1}$
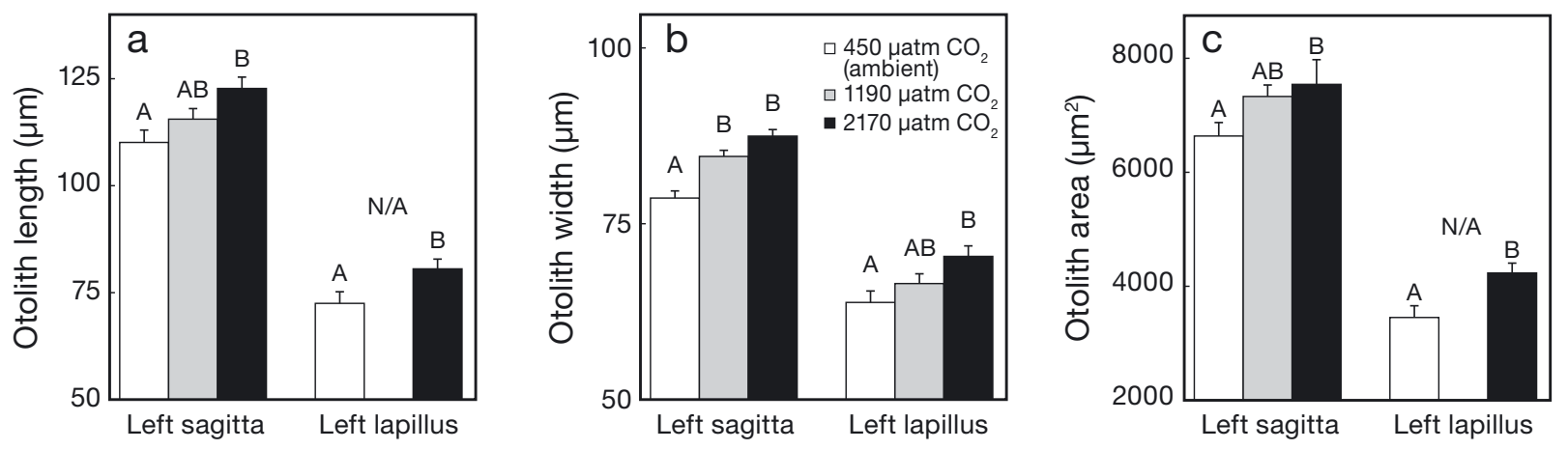

Fig. 4. Effects of ocean acidification on sagittal and lapillar otolith (a) length, (b) width, and (c) area for 20 day post hatch (dph) larval mahi-mahi during Expt 3. Results are from ANCOVA of left lapillus and left sagitta. In (a) and (c), the slope of the regression of left lapillus length and area against fish standard length differed from other treatments; therefore it was removed from analysis. Within each otolith type, bars not sharing a letter are significantly different (Tukey's p < 0.05). Values are adjusted tank means $+\mathrm{SE}\left(\mathrm{n}=4\right.$ treatment $\left.^{-1}\right)$

larvae exposed to acidification were of greater sizeat-age and had decreased routine swimming activity than controls during Expt 2, and acidification also resulted in significant otolith overgrowth compared to controls during Expt 3. The absence of major impacts of acidification on mahi-mahi larvae is consistent with the concept that some resistance to acidification may be possible in species with the ability to maintain tight physiological regulation of their internal environment, a general trait of organisms with high metabolic rates (Melzner et al. 2009a). By maintaining tight control over internal $\mathrm{pH}$, mahi-mahi may be able to avoid reduced protein biosynthesis that occurs at lower $\mathrm{pH}$ (Langenbuch \& Pörtner 2003), thus preventing negative impacts on size and development. Alternatively, more extensive effects of increased $p \mathrm{CO}_{2}$ may have been too subtle to be detected during the present study.

During Expt 1, it is possible that an effect of acidification on growth and development was masked by temperature-driven depression of metabolic and growth rates across controls and treatments. Due to seasonal variation in source seawater, Expt 1 was conducted at the lowest average temperature $\left(\sim 24^{\circ} \mathrm{C}\right)$ and larvae were observed to grow and develop at the slowest rates of any experiment. If acidification impacted the metabolism of larvae, which could be manifested as either a depression (Pörtner et al. 2005) or increase in metabolic rate (Miller et al. 2012), the magnitude of this effect could have been reduced to the point of non-detection due to the overall lower metabolic rates and slower growth.

During early development (5 and $8 \mathrm{dph}$ ), mahi-mahi larvae in Expt 2 exhibited an increase in size and developmental rate in high- $\mathrm{CO}_{2}$ seawater. The growthmortality hypothesis suggests that such results could be beneficial to larval survival in the wild, allowing them to pass through gape-limited predation windows more quickly than smaller larvae (Anderson 1988). 
Table 4. Summary of statistical results from ANOVA of proportion of mahi-mahi larvae hatched (Hatch), standard length (SL), critical swimming speed $\left(U_{\text {crit }}\right)$, and otolith size/shape across multiple days post hatch (dph) during Expt 3. ANCOVA results presented for otolith length, width, and area are from left lapillus (LL) and left sagitta (LS). Significant results $(p<0.05)$ are shown in bold. Regression slopes for LL length and area of $1190 \mu$ atm $p \mathrm{CO}_{2}$ treatment otoliths differed from ambient and $2170 \mu \mathrm{atm} p \mathrm{CO}_{2}$ treatments, and were therefore removed from analysis. Tukey's post-hoc test results compare ambient $p \mathrm{CO}_{2}(\mathrm{C}), 1190 \mu \mathrm{atm}$ $p \mathrm{CO}_{2}(1)$, and $2170 \mu \mathrm{atm} p \mathrm{CO}_{2}(2)$ treatments

\begin{tabular}{|lrccc|}
\hline Metric & $F$ & $\mathrm{p}$ & $\mathrm{df}$ & Tukey's \\
\hline Hatch & 3.475 & 0.076 & 2,9 & $\mathrm{C}=1=2$ \\
SL (dph) & & & & \\
0 & 0.817 & 0.472 & 2,9 & $\mathrm{C}=1=2$ \\
2 & 1.546 & 0.265 & 2,9 & $\mathrm{C}=1=2$ \\
6 & 0.909 & 0.437 & 2,9 & $\mathrm{C}=1=2$ \\
21 & 0.802 & 0.482 & 2,9 & $\mathrm{C}=1=2$ \\
$\boldsymbol{U}_{\text {crit }}$ (dph) & & & & \\
20 & 2.091 & 0.179 & 2,9 & $\mathrm{C}=1=2$ \\
Otolith size/shape & & & & \\
LS length & 6.797 & $\mathbf{0 . 0 2 3}$ & 2,7 & $1=\mathrm{C}<2=1$ \\
LS width & 28.444 & $<\mathbf{0 . 0 0 1}$ & 2,7 & $\mathrm{C}<1=2$ \\
LS area & 11.321 & $\mathbf{0 . 0 0 6}$ & 2,7 & $1=\mathrm{C}<2=1$ \\
LS rectangularity & 0.321 & 0.735 & 2,8 & $\mathrm{C}=1=2$ \\
LS roundness & 1.795 & 0.227 & 2,8 & $\mathrm{C}=1=2$ \\
LL length & 8.529 & $\mathbf{0 . 0 4 3}$ & 1,4 & $\mathrm{C}<2$ \\
LL width & 5.806 & $\mathbf{0 . 0 3 3}$ & 2,7 & $1=\mathrm{C}<2=1$ \\
LL area & 13.948 & $\mathbf{0 . 0 2 0}$ & 1,4 & $\mathrm{C}<2$ \\
LL rectangularity & 0.381 & 0.695 & 2,8 & $\mathrm{C}=1=2$ \\
LL roundness & 0.939 & 0.430 & 2,8 & $\mathrm{C}=1=2$ \\
\hline
\end{tabular}

This is not the first report of an increase in the size-atage of larval fish under acidified conditions. Chambers et al. (2014) reported a temporary increase in the length-at-age of larval flounder under elevated $p \mathrm{CO}_{2}$ conditions (1808 and $4714 \mathrm{ppm}$ ), during the first $2 \mathrm{wk}$ of development. Additionally, damselfish larvae reared at elevated $p \mathrm{CO}_{2}$ (550 to $1030 \mathrm{ppm}$ ) exhibited up to an $18 \%$ increase in length-at-age, which the authors suggested could be accomplished either through increased energy intake or decreased energy expenditure (Munday et al. 2009). In a captive rearing environment, prey are consistently provided at higher quantities than what is expected in nature; thus, larvae in the present study may have been able to increase their energy intake to compensate, or overcompensate, for an increase in the metabolic cost of acid-base balance under acidified conditions (Deigweiher et al. 2008, Miller et al. 2012). This has been demonstrated with mussels in both laboratory and natural marine environments, where food availability predominantly influences growth compared to increased $p \mathrm{CO}_{2}$ (Thomsen et al. 2013). Reduced energy expenditure is also possible through either metabolic depression or behavioral acclimation. Young mahimahi larvae (3 dph) reduce their metabolism under ocean acidification conditions (Pimentel et al. 2014b), a phenomenon that occurs in other marine organisms as well (Langenbuch \& Pörtner 2003). However, metabolic depression would likely result in reduced growth (Pörtner et al. 2004); therefore, a more likely explanation of increased size-at-age may be a reduction in energy expenditure via altered behavioral activity, as was observed for swimming velocity at the same age and during the same experiment (Expt 2) when increased size was detected. A reduction in swimming velocity could help compensate for possible $\mathrm{CO}_{2}$-driven increases in the metabolic cost of acidbase regulation, allowing for re-allocation of metabolic resources to somatic growth. Pimentel et al. (2014b) also reported altered swimming behavior in mahimahi larvae approximately 3 to $5 \mathrm{~d}$ younger than those in our study, under slightly higher $p \mathrm{CO}_{2}$ conditions (1670 $\mu \mathrm{atm})$, though there was no corresponding change in larval size. In the present study, differences in larval size among treatments decreased to a point of non-significance after $8 \mathrm{dph}$, suggesting that this behavioral response or its effectiveness may be transient.

Reduced routine swimming velocity may have important ecological implications for the feeding and survival of larvae in the wild. Prey encounter rate is directly related to predator swimming speed (Gerritsen \& Strickler 1977), thus larvae under elevated $p \mathrm{CO}_{2}$ conditions may exhibit reduced feeding success due to lower encounter rates. This would not be evident in a laboratory scenario with abundant availability of prey, but could be critical in nature, where starvation is thought to be an important process influencing larval survival and recruitment magnitude (Houde 1989). Reduced food intake also has the potential to interact with larval susceptibility to elevated $p \mathrm{CO}_{2}$ : for example, cobia exhibit reduced starvation resistance under acidified conditions (Bignami 2013). This combination of effects could negatively influence cumulative survival through the larval stages and result in lower recruitment magnitude into the adult population.

During Expt 3, we observed no significant change in hatch rate or $U_{\text {crit }}$ under elevated $p \mathrm{CO}_{2}$ treatments. These $U_{\text {crit }}$ results are consistent with other species at various ontogenetic stages (Melzner et al. 2009b, Munday et al. 2009, Bignami et al. 2013a). Not surprisingly, otolith growth was higher in larvae raised 
under acidified conditions. This has been observed in a number of species (e.g. Checkley et al. 2009, Munday et al. 2011a, Bignami et al. 2013b) and is thought to be caused by the establishment of a more favorable calcifying environment through the retention of bicarbonate ions in the extracellular fluid, a physiological mechanism used by fishes to compensate for increased blood $p \mathrm{CO}_{2}$ during hypercapnic events (Esbaugh et al. 2012). The presence, absence, or severity of otolith overgrowth may be directly related to the magnitude of this physiological response as well as the non-carbonate blood buffer capacity of different species. The lowest $p \mathrm{CO}_{2}$ known to affect otolith development is 800 patm, for $21 \mathrm{dph}$ cobia (Bignami et al. 2013a), while in other species much higher treatments ( 4000 $\mu \mathrm{atm})$ have failed to induce a significant change (Frommel et al. 2013). Otolith size and density influences the function of otoliths as auditory sensory organs: modeling of larval cobia otoliths with up to $58 \%$ greater mass indicated increased auditory sensitivity and a $\sim 50 \%$ extension of hearing range (Bignami et al. 2013b). In the present study, we found an increase in otolith size; thus mass is likely to be increased as well, which could similarly impact the auditory sensitivity and hearing range of mahi-mahi larvae. Although mahi-mahi do not navigate and recruit to a noisy benthic environment like many reef fishes, auditory sensation likely plays an important role in prey detection, communication, and navigation in the pelagic environment.

This study provides perspective on the impact of acidification on the larvae of a species with a similar life history strategy and physiological characteristics as other offshore pelagic fishes. The impacts on growth, behavior, and otolith development reported here, along with metabolic and behavioral effects reported by Pimentel et al. (2014b), indicate that mahi-mahi are not immune to the impacts of ocean acidification. However, neither mahi-mahi nor other pelagic species such as cobia have demonstrated substantially greater susceptibility to ocean acidification than the nearshore demersal species that are presumably better adapted to variable environmental conditions (Munday et al. 2008, Pörtner 2008). Although these findings offer a potentially optimistic outlook for the future of large pelagic species in the face of ocean acidification, research on entirely pelagic tropical species remains limited. Furthermore, the present study did not address several important factors, such as more subtle impacts of acidification, the cumulative effect of long-term exposure to ocean acidification and its potential effects on growth and reproduction (Pörtner et al. 2005), or the combined effect of multiple stressors, which fishes will experience as a result of climate change. Continued study of the impacts of ocean acidification on species with distinct life history characteristics will strengthen our knowledge of the diversity of ecological responses to acidification and enable informed management and conservation decisions.

Acknowledgements. All live animal use was conducted with the approval of the University of Miami Institutional Animal Care and Use Committee (protocol \#12-075). This study was supported by grants from the National Science Foundation GK-12 program, University of Miami Maytag Ichthyology Chair, Guy Harvey Ocean Foundation, Florida Sea Grant, International Light Tackle Tournament Association, International Women's Fishing Association, Manasquan River Marlin and Tuna Club, and the Yamaha Contender/Miami Billfish Tournament. We thank UMEH, T. Capo, D. Benetti, C. Langdon, K. Ternus, C. Li, M. Iwane, D. Martin, M. Huebner, and A. Rivard for facility use and assistance, as well as M. Grosell and J. Dallman for discussions. We also thank P. Munday for helpful information and discussion on swimming flume design.

\section{LITERATURE CITED}

Anderson J (1988) A review of size dependent survival during pre-recruit stages of fishes in relation to recruitment. J Northwest Atl Fish Sci 8:1-12

Baumann H, Talmage SC, Gobler CJ (2011) Reduced early life growth and survival in a fish in direct response to increased carbon dioxide. Nat Clim Change 2:38-41

Beardsley GL Jr (1967) Age, growth, and reproduction of the dolphin, Coryphaena hippurus, in the Straits of Florida. Copeia 1967:441-451

Benetti DD, Sardenberg B, Welch A, Hoenig R, Orhun MR, Zink I (2008) Intensive larval husbandry and fingerling production of cobia Rachycentron canadum. Aquaculture 281:22-27

Bignami S (2013) Effects of ocean acidification on the early life history of two pelagic tropical fish species, cobia (Rachycentron canadum) and mahi-mahi (Coryphaena hippurus). PhD dissertation, University of Miami, Coral Gables, FL

> Bignami S, Sponaugle S, Cowen RK (2013a) Response to ocean acidification in larvae of a large tropical marine fish, Rachycentron canadum. Glob Change Biol 19: 996-1006

Bignami S, Enochs IC, Manzello DP, Sponaugle S, Cowen RK (2013b) Ocean acidification alters the otoliths of a pantropical fish species with implications for sensory function. Proc Natl Acad Sci USA 110:7366-7370

Brauner C (2008) Acid-base balance. In: Finn RN, Kapoor BG (eds) Fish larval physiology. Science Publishers, Enfield, NH, p 185-198

Brown GE (2003) Learning about danger: chemical alarm cues and local risk assessment in prey fishes. Fish Fish 4 : 227-234

Caldeira K, Wickett ME (2003) Anthropogenic carbon and ocean $\mathrm{pH}$. Nature 425:365

Caldeira K, Wickett ME (2005) Ocean model predictions of chemistry changes from carbon dioxide emissions to the 
atmosphere and ocean. J Geophys Res 110:C09S04, doi: 1029/2004JC002671

> Chambers RC, Candelmo AC, Habeck EA, Poach ME and others (2014) Effects of elevated $\mathrm{CO}_{2}$ in the early life stages of summer flounder, Paralichthys dentatus, and potential consequences of ocean acidification. Biogeosciences 11:1613-1626

> Checkley DM, Dickson AG, Takahashi M, Radich JA, Eisenkolb N, Asch R (2009) Elevated $\mathrm{CO}_{2}$ enhances otolith growth in young fish. Science 324:1683

Cowen RK, Sponaugle S (2009) Larval dispersal and marine population connectivity. Annu Rev Mar Sci 1:443-466

Deigweiher K, Koschnick N, Pörtner HO, Lucassen M (2008) Acclimation of ion regulatory capacities in gills of marine fish under environmental hypercapnia. Am J Physiol 295:R1660-R1670

del Carmen Alvarez M, Fuiman L (2005) Environmental levels of atrazine and its degradation products impair survival skills and growth of red drum larvae. Aquat Toxicol 74:229-241

Ditty JG, Shaw RF, Grimes CB, Cope JS (1994) Larval development, distribution, and abundance of common dolphin, Coryphaena hippurus, and pompano dolphin, $C$. equiselis (family: Coryphaenidae), in the northern Gulf of Mexico. Fish Bull 92:275-291

Esbaugh AJ, Heuer R, Grosell M (2012) Impacts of ocean acidification on respiratory gas exchange and acid-base balance in a marine teleost, Opsanus beta. J Comp Physiol B 182:921-934

FAO (2013) Species fact sheets, Coryphaena hippurus (Linnaeus, 1758). www.fao.org/fishery/species/3130/en (accessed on 11 Mar 2013)

> Faulk CK, Holt GJ (2005) Advances in rearing cobia Rachycentron canadum larvae in recirculating aquaculture systems: live prey enrichment and greenwater culture. Aquaculture 249:231-243

Feely RA, Sabine CL, Hernandez-Ayon JM, Ianson D, Hales B (2008) Evidence for upwelling of corrosive 'acidified' water onto the continental shelf. Science 320:1490-1492

Ferrari MCO, McCormick M, Munday PL, Meekan MG, Dixson DL, Lönnstedt O, Chivers DP (2012) Effects of ocean acidification on visual risk assessment in coral reef fishes. Funct Ecol 26:553-558

Folpp H, Lowry M (2006) Factors affecting recreational catch rates associated with a fish aggregating device (FAD) off the NSW coast, Australia. Bull Mar Sci 78: 185-193

> Frieder CA, Nam SH, Martz TR (2012) High temporal and spatial variability of dissolved oxygen and $\mathrm{pH}$ in a nearshore California kelp forest. Biogeosciences 9:3917-3930

Frommel AY, Maneja R, Lowe D, Malzahn AM and others (2011) Severe tissue damage in Atlantic cod larvae under increasing ocean acidification. Nat Clim Change 2:42-46

Frommel AY, Schubert A, Piatkowski U, Clemmesen C (2013) Egg and early larval stages of Baltic cod, Gadus morhua, are robust to high levels of ocean acidification. Mar Biol 160:1825-1834

Gattuso JP (2010) Approaches and tools to manipulate the carbonate chemistry. In: Riebesell U, Fabry V, Hannson L, Gattuso JP (eds) Guide to best practices for ocean acidification research and data reporting. Publications office of the European Union, Luxembourg, p 44-52

Gerritsen J, Strickler JR (1977) Encounter probabilities and community structure in zooplankton: a mathematical model. Can J Fish Aquat Sci 34:73-82
Hamilton TJ, Holcombe A, Tresguerres $\mathrm{M}$ (2014) $\mathrm{CO}_{2^{-}}$ induced ocean acidification increases anxiety in Rockfish via alteration of $\mathrm{GABA}_{\mathrm{A}}$ receptor functioning. Proc R Soc Lond B Biol Sci 281:20132509

- Hammer C (1995) Fatigue and exercise tests with fish. Comp Biochem Physiol A 112:1-20

Harwell MR, Rubinstein EN, Hayes WS, Olds CC (1992) Summarizing Monte Carlo results in methodological research: the one-and two-factor fixed effects ANOVA cases. J Educ Behav Stat 17:315-339

- Hofmann GE, Smith JE, Johnson KS, Send U and others (2011) High-frequency dynamics of ocean pH: a multiecosystem comparison. PLoS ONE 6:e28983

Holmes TH, McCormick M (2010) Smell, learn and live: the role of chemical alarm cues in predator learning during early life history in a marine fish. Behav Processes 83: 299-305

Houde ED (1989) Comparative growth, mortality, and energetics of marine fish larvae: temperature and implied latitudinal effects. Fish Bull 87:471-495

Hurst TP, Fernandez ER, Mathis JT, Miller JA (2012) Resiliency of juvenile walleye pollock to projected levels of ocean acidification. Aquat Biol 17:247-259

Kroeker KJ, Kordas RL, Crim R, Hendriks IE and others (2013) Impacts of ocean acidification on marine organisms: quantifying sensitivities and interaction with warming. Glob Change Biol 19:1884-1896

> Langdon C, Takahashi T, Sweeney C, Chipman D and others (2000) Effect of calcium carbonate saturation state on the calcification rate of an experimental coral reef. Global Biogeochem Cycles 14:639-654

> Langenbuch M, Pörtner HO (2003) Energy budget of hepatocytes from Antarctic fish (Pachycara brachycephalum and Lepidonotothen kempi) as a function of ambient $\mathrm{CO}_{2}$ : pH-dependent limitations of cellular protein biosynthesis? J Exp Biol 206:3895-3903

Lewis E, Wallace D (1998) CO2SYS - Program developed for the $\mathrm{CO}_{2}$ system calculations. Carbon Dioxide Information Analysis Center, Oak Ridge National Laboratory, US Dept of Energy, Oak Ridge, TN

Mathis A, Chivers DP, Smith RJF (1995) Chemical alarm signals: Predator deterrents or predator attractants? Am Nat 145:994-1005

Meehl G, Stocker TF, Collins W, Friedlingstein P and others (2007) Global climate projections. In: Solomon S, Qin D, Manning $\mathrm{M}$, Chen $\mathrm{Z}$ and others (eds) Climate change 2007: the physical science basis. Contribution of Working Group I to the Fourth Assessment Report of the Intergovernmental Panel on Climate Change. Cambridge University Press, Cambridge, p 748-845

Meijering E, Dzyubachyk O, Smal I (2012) Methods for cell and particle tracking. In: Conn PM (ed) Methods in enzymology, Vol 504: imaging and spectroscopic analysis of living cells. Elsevier, London, p 183-200

- Meinshausen M, Smith SJ, Calvin K, Daniel JS and others (2011) The RCP greenhouse gas concentrations and their extensions from 1765 to 2300. Clim Change 109:213-241

Melzner F, Goebel S, Langenbuch M, Gutowska MA, Pörtner HO, Lucassen M (2009b) Swimming performance in Atlantic Cod (Gadus morhua) following long-term (4-12 months) acclimation to elevated seawater $p \mathrm{CO}_{2}$. Aquat Toxicol 92:30-37

Melzner F, Gutowska MA, Langenbuch M, Dupont S and others (2009a) Physiological basis for high $\mathrm{CO}_{2}$ tolerance in marine ectothermic animals: Pre-adaptation 
through lifestyle and ontogeny? Biogeosciences 6: 2313-2331

Melzner F, Thomsen J, Koeve W, Oschlies A and others (2013) Future ocean acidification will be amplified by hypoxia in coastal habitats. Mar Biol 160:1875-1888

Miller GM, Watson SA, Donelson JM, McCormick M, Munday PL (2012) Parental environment mediates impacts of increased carbon dioxide on a coral reef fish. Nat Clim Change 2:858-861

Munday PL, Jones GP, Pratchett MS, Williams AJ (2008) Climate change and the future for coral reef fishes. Fish Fish 9:261-285

Munday PL, Donelson JM, Dixson DL, Endo GGK (2009) Effects of ocean acidification on the early life history of a tropical marine fish. Proc R Soc Lond B Biol Sci 276: 3275-3283

Munday PL, Dixson DL, McCormick M, Meekan M, Ferrari MCO, Chivers DP (2010) Replenishment of fish populations is threatened by ocean acidification. Proc Natl Acad Sci USA 107:12930-12934

Munday PL, Hernaman V, Dixson DL, Thorrold SR (2011a) Effect of ocean acidification on otolith development in larvae of a tropical marine fish. Biogeosciences 8: 1631-1641

> Munday PL, Gagliano M, Donelson JM, Dixson DL, Thorrold SR (2011b) Ocean acidification does not affect the early life history development of a tropical marine fish. Mar Ecol Prog Ser 423:211-221

Naas KE, Naess T, Harboe T (1992) Enhanced first feeding of halibut larvae (Hippoglossus hippoglossus L.) in green water. Aquaculture 105:143-156

Nilsson GE, Dixson DL, Domenici P, McCormick M, Sørensen C, Watson SA, Munday PL (2012) Near-future carbon dioxide levels alter fish behaviour by interfering with neurotransmitter function. Nat Clim Change 2:201-204

> Oxenford HA (1999) Biology of the dolphinfish (Coryphaena hippurus) in the western central Atlantic: a review. Sci Mar 63:303-315

Palko BJ, Beardsley GL Jr, Richards WJ (1982) Synopsis of the biological data on dolphin-fishes, Coryphaena hippurus Linnaeus and Coryphaena equiselis Linnaeus. NOAA Tech Rep, NMFS Circ 443, US Dept of Commerce, Washington, DC

Pimentel MS, Faleiro F, Dionísio G, Repolho T, Pousão-

Editorial responsibility: Christine Paetzold, Oldendorf/Luhe, Germany
Ferreira P, Machado J, Rosa R (2014a) Defective skeletogenesis and oversized otoliths in fish early stages in a changing ocean. J Exp Biol 217:2062-2070

Pimentel M, Pegado M, Repolho T, Rosa R (2014b) Impact of ocean acidification in the metabolism and swimming behavior of the dolphinfish (Coryphaena hippurus) early larvae. Mar Biol 161:725-729

Pörtner HO (2008) Ecosystem effects of ocean acidification in times of ocean warming: a physiologist's view. Mar Ecol Prog Ser 373:203-217

Pörtner HO, Langenbuch M, Reipschläger A (2004) Biological impact of elevated ocean $\mathrm{CO}_{2}$ concentrations: lessons from animal physiology and earth history. J Oceanogr 60: 705-718

> Pörtner HO, Langenbuch M, Michaelidis B (2005) Synergistic effects of temperature extremes, hypoxia, and increases in $\mathrm{CO}_{2}$ on marine animals: from Earth history to global change. J Geophys Res 110:C09S10, doi:1029/2004 JC002561

> Potoschi A, Cannizzaro L, Milazzo A, Scalisi M, Bono G (1999) Sicilian dolphinfish (Coryphaena hippurus) fishery. Sci Mar 63:439-445

> Price NN, Martz TR, Brainard RE, Smith JE (2012) Diel variability in seawater $\mathrm{pH}$ relates to calcification and benthic community structure on coral reefs. PLoS ONE 7:e43843

Stobutzki I, Bellwood D (1997) Sustained swimming abilities of the late pelagic stages of coral reef fishes. Mar Ecol Prog Ser 149:35-41

Thomsen J, Gutowska MA, Saphörster J, Heinemann A and others (2010) Calcifying invertebrates succeed in a naturally $\mathrm{CO}_{2}$ enriched coastal habitat but are threatened by high levels of future acidification. Biogeosciences Discuss 7:5119-5156

Thomsen J, Casties I, Pansch C, Körtzinger A, Melzner F (2013) Food availability outweighs ocean acidification effects in juvenile Mytilus edulis: laboratory and field experiments. Glob Change Biol 19:1017-1027

Underwood AJ (1997) Experiments in ecology: their logical design and interpretation using analysis of variance. Cambridge University Press, Cambridge

Zúñiga Flores MS, Ortega-García S, Klett-Traulsen A (2008) Interannual and seasonal variation of dolphinfish (Coryphaena hippurus) catch rates in the southern Gulf of California, Mexico. Fish Res 94:13-17

Submitted: March 24, 2014; Accepted: August 14, 2014

Proofs received from author(s): October 20, 2014 